2021 TheoLogica

An International Journal for Philosophy of Religion and Philosophical Theology

S. I. THEOLOGICAL EXPLORATIONS IN TIME AND SPACE

DOI : $\underline{\text { https://doi.org/10.14428/thl.v5i1.60693 }}$

\title{
A Reply to Wielenberg on a Timeless First Cause
}

WILLIAM LANE CRAIG

Talbot School of Theology, Biola University

Houston Baptist University

william.lane.craig@biola.edu

\begin{abstract}
Erik Wielenberg seeks to advance his critique of the kalām cosmological argument by putting forward three further criticisms of the view that God is temporal since the moment of creation. It is seen that these criticisms are misconceived and do not take cognizance of what I have written elsewhere.
\end{abstract}

Keywords: Divine eternity, Timelessness, Creation, Singularity, God and time

I am grateful to the guest editors of TheoLogica for this opportunity to reply to Erik Wielenberg's counter-response to my response to his critique of a theistic account of the origin of the universe. His counter-response is prompted by the fact that my response was to an unrevised version of his article that differed somewhat from the revised, final version, which I had not seen. To make clear the crucial difference, I here exhibit the original version (OV) and the final version (FV):

OV. "God must be temporal at $\mathrm{t} 1$ because the universe exists at $\mathrm{t} 1$; yet $\mathrm{He}$ must be timeless at $\mathrm{t} 1$ in order to have the power to create the universe at $\mathrm{t} 1$. "

FV: “God must be temporal at $\mathrm{t} 1$ because the universe exists at $\mathrm{t} 1$; yet He must be timeless at $\mathrm{t} 1$ in order to have, at $\mathrm{t} 1$, the power to create the universe."

(OV) does not specify when God has the power in question, whereas (FV) does; and $(\mathrm{OV})$ specifies the power to create the universe at $t 1$, whereas (FV) specifies simply the power to create the universe.

Had I seen (FV), my response would have been that it ascribes to me a logically incoherent view to which I do not subscribe. It is logically incoherent to say that a timeless God has at $\mathrm{t} 1$ a certain power. A timeless God does not even exist at $\mathrm{t} 1$, much less possess any properties at that time. Something that does not exist at a time 
cannot possess any properties at that time, since there is literally nothing then to possess them.

So God must exist at $\mathrm{t} 1$ in order to have at $\mathrm{t} 1$ the power to create the universe. Indeed, along with considerations stemming from God's knowledge of tensed facts, God's causal relation to the universe at $\mathrm{t} 1$ is the motivation for my maintaining that God is temporal since the moment of creation. My studied view, defended at length, is that God is timeless sans creation and in time since the moment of creation. ${ }^{1}$

Now in his counter-response, Wielenberg makes three further claims, which I shall consider in order. My view allegedly:

(i) is at odds with my characterization of the universe as a temporal effect of a timeless cause. Even if this charge were true, it would at best show that I am guilty of infelicitous use of language, not that my studied view is incoherent or false. I have stated and defended my studied view clearly, and any infelicitous expressions need to be read in that light. But are expressions like "given that time had a beginning, the cause of the beginning of time must be timeless" infelicitous? Not if the singular term "the cause of the beginning of time" is used referentially rather than attributively. ${ }^{2}$ To illustrate, the man who says, "I never kissed my wife before we were married" (because at that time she was not his wife!) is using the term "my wife" attributively, not referentially, in order to make a joke. More seriously, we can speak referentially of God sans the universe as the cause of the universe in order to convey that the cause of the universe did not itself spring into being at the moment of creation.

(ii) renders God in His timeless phase causally inert and so leaves us with no grounds to posit the existence of a timeless God. I prefer to characterize God sans the universe as causally inactive rather than inert. But why posit the existence of a timeless God? As I indicated in my response to Wielenberg, the proponent of the KCA need not be committed to divine timelessness. He could hold with Lucas, Swinburne, and Padgett that God exists sans the universe in a sort of non-metric time in which temporal intervals and events do not exist, so that the impossibility of an infinite regress of events does not entail a beginning of time itself. But I have argued at some length for the greater plausibility of the view that God is timeless sans creation, and there is no reason to rehearse those arguments here. ${ }^{3}$

\footnotetext{
${ }^{1}$ God, Time and Eternity (2001). For a popular account see my Time and Eternity: Exploring God's Relationship to Time (2001).

2 On this distinction see Keith Donnellan, "Reference and Definite Descriptions" (1966, 287).

${ }^{3}$ God, Time and Eternity, chap. 9; Time and Eternity, pp. 233-36. It occurs to me upon further reflection that perhaps Wielenberg is asking why posit God at all. The answer is that if God exists at $\mathrm{t} 1$ but not sans the universe, then He begins to exist at $\mathrm{t} 1$ and so would require a cause. Recall what I
} 
(iii) opens the door to non-theistic explanations of the beginning of the universe. This is a very important objection which is independent of my view of divine eternity. Why not say that the initial cosmological singularity is the explanation of the beginning of the universe? Well, various reasons: The universe is comprised of spacetime and its boundary points, so that if the universe began to exist, there must be a transcendent cause of the universe. Moreover, the initial singularity, though not in physical time, is plausibly in metaphysical time, since it is the earliest state of the universe and the universe evolved from it. It comes into being and passes away. It is inaccurate to think, as Wielenberg says, that "When First Expansion occurs, Singularity 'enters' time." No, the initial cosmological singularity lasts no longer than an instant and is nowhere to be found today. As such it is neither timeless nor past eternal and so requires a cause. Furthermore, even if the singularity were timeless, it is causally connected with the temporal universe, and the only way to explain the rise of a temporal effect with a beginning from a timeless cause, as I have argued, is if that cause is a personal agent endowed with freedom of the will. ${ }^{4}$

So while I am grateful to Wielenberg for drawing further attention to such fascinating issues, I do not think that his further critique is any more successful than his original.

\section{Bibliography}

Keith Donnellan. 1966. "Reference and Definite Descriptions." Philosophical Review 75: 281-304. https://doi.org/10.2307/2183143.

William Lane Craig. 1979. The Kalām Cosmological Argument. London: Macmillan. William Lane Craig. 2001a. God, Time and Eternity. Dordrecht: Kluwer Academic Publishers.

William Lane Craig. 2001b. Time and Eternity: Exploring God's Relationship to Time. Wheaton, Ill.: Crossway.

Published Online: February 25, 2021

said in my original response to Wielenberg's second alleged contradiction concerning how on a relational view of time God's creating the universe brings about the first moment of time.

${ }^{4}$ The Kalām Cosmological Argument (1979, 149-53). 